\title{
Allogeneic CD3- CD19- Selected Natural Killer Cells
}

National Cancer Institute

\section{Source}

National Cancer Institute. Allogeneic CD3-CD19-Selected Natural Killer Cells. NCI

Thesaurus. Code C121445.

Human leukocyte antigen (HLA)-haploidentical donor-derived natural killer (NK) cells that are activated with the cytokine interleukin-15 (IL-15), with immunomodulating and antineoplastic activities. Upon leukapheresis, the HLA-haploidentical donor peripheral blood mononuclear cells (PBMCs) are treated to remove T-lymphocytes (CD3+) and Blymphocytes (CD19+) cells. In turn, NK cells are expanded and activated with IL-15. Upon infusion of the allogeneic CD3- CD19- selected NK cells, these cells recognize and bind to tumor cells, and secrete perforins, granzymes, and cytokines, which results in cancer cell lysis. 